JD

74,4

692

Received 9 July 2017

Revised 12 November 2017

Accepted 12 November 2017

\section{The relationship between students' subject preferences and their information behaviour}

\author{
Andrew D. Madden \\ Department of Information Management, Lingnan College, \\ Sun Yat-sen University, Guangzhou, China \\ Sheila Webber and Nigel Ford \\ Information School, University of Sheffield, Sheffield, UK, and \\ Mary Crowder \\ University of Sheffield, Sheffield, UK
}

\begin{abstract}
Purpose - The purpose of this paper is to investigate the relationship between preferred choice of school subject and student information behaviour (IB).

Design/methodology/approach - Mixed methods were employed. In all, 152 students, teachers and librarians participated in interviews or focus groups. In total, 1,375 students, key stage 3 (11-14 years) to postgraduate, responded to a questionnaire. The research population was drawn from eight schools, two further education colleges and three universities. Insights from the literature review and the qualitative research phase led to a hypothesis which was investigated using the questionnaire: that students studying hard subjects are less likely to engage in deep IB than students studying soft subjects.

Findings - Results support the hypothesis that preferences for subjects at school affect choice of university degree. The hypothesis that a preference for hard or soft subjects affects IB is supported by results of an analysis in which like or dislike of maths/ICT is correlated with responses to the survey. Interviewees' comments led to the proposal that academic subjects can be classified according to whether a subject helps students to acquire a "tool of the Mind" or to apply such a tool. A model suggesting how IB may differ depending on whether intellectual tools are being acquired or applied is proposed.

Practical implications - The "inner logic" of certain subjects and their pedagogies appears closely linked to IB. This should be considered when developing teaching programmes.

Originality/value - The findings offer a new perspective on subject classification and its association with IB, and a new model of the association between IB and tool acquisition or application is proposed, incorporating the perspectives of both teacher and student.
\end{abstract}

Keywords Students, Schools, Universities, Critical thinking, Information research, Information behaviour, Disciplines

Paper type Research paper

\section{Introduction}

This paper reports selected findings from a study funded by the Arts and Humanities Research Council entitled "Developing Deep Critical Information Behaviour (IB)". The project ran from 2010 to 2012 and investigated the nature, extent and pattern of occurrence of deep and surface IBs amongst students at secondary school and university, studying in England. It also sought to investigate the extent to which, in the view of key stakeholders (i.e. educators, librarians and administrators), the development of deep IB could be enabled and fostered. The project used a mixed-methods approach: stage 1

(c) Andrew D. Madden, Sheila Webber, Nigel Ford and Mary Crowder. Published by Emerald Publishing Limited. This article is published under the Creative Commons Attribution (CC BY 4.0) licence. Anyone may reproduce, distribute, translate and create derivative works of this article (for both commercial and non-commercial purposes), subject to full attribution to the original publication and authors. The full terms of this licence may be seen at http://creativecommons.org/licences/by/4.0/legalcode 
comprised interviews and focus groups with learners and stakeholders; and stage 2 consisted of a questionnaire-based survey carried out in schools, colleges and universities in South Yorkshire and the Midlands.

The analysis reported here focusses on the relationship between students' preferred choice of school subject and their IB (as self-reported, or reported by stakeholders). As well as probing respondents' attitudes towards using information for their school work, the questionnaire survey asked them to nominate the subjects they most liked and disliked on the English National Curriculum. Thus this paper connects two areas of IB research: learners' IB in formal education, and differences in IB relating to academic discipline.

The underlying research problem is that of young people's critical engagement with information. Julien and Barker (2009, p. 12) noted that:

Widespread concern about a lack of searching skills and critical information evaluation skills, particularly among students, is evident in the literature. [...] Taken as a whole, then, the research literature on information literacy skills among students demonstrates that students' skills are generally lacking.

These concerns have not abated in the intervening years (Goldman et al., 2016). For example Coiro et al. (2015) found that only 25 per cent of a stratified random sample of North American 12-13 year olds used appropriate criteria to judge information quality. Indeed, the information landscape has become more complex and problematic: recent studies have indicated that people cede critical judgements to search engines (Sundin et al., 2017) and lack critical awareness of news filtering (Powers, 2017).

\subsection{Definition of terms}

In the context of this study, information is held to be "a stimulus which [...] amends the World View of the informed" (Madden, 2004, p. 9). In other words, when students see or hear something that alters their understanding of the world and/or their place within it, they are considered to be receiving information.

This understanding of information accords well with prevailing views of IB. Wilson, who originally coined the term IB (Wilson, 1981), defined it as:

$[\ldots]$ the totality of human behavior in relation to sources and channels of information, including both active and passive information seeking, and information use. Thus, it includes face-to-face communication with others, as well as the passive reception of information as in, for example, watching TV advertisements, without any intention to act on the information given (Wilson, 2000, p. 49).

As Case and Given (2016, p. 6) notes, IB therefore includes browsing and encountering information; and the study of IB addresses "how people need, seek, give and use information in different contexts" (Pettigrew et al., 2001, p. 44). These contexts may be everyday life, life out of the ordinary (e.g. transition or crisis), the workplace, or formal education. This paper considers aspects of IB that relate to the latter and explores the question of whether students' subject preferences and choices impact on the extent to which they seek for, evaluate and use information and the ways in which they go about it.

\section{Literature review}

This review focusses on three key areas:

(1) research which provides frameworks for analysing students' critical thinking, IB and learning;

(2) research into learners' epistemological understandings; and 
JD

74,4

(3) disciplinarity, and research into disciplinary differences in students' IB and learning, and in teachers' approaches to teaching.

The review finishes by describing key features of the context for the research study, i.e. the English secondary and tertiary education systems.

\subsection{Frameworks for students' critical thinking, IB and learning}

This section identifies research-based frameworks which can be used to categorise students' approaches to critical thinking, IB and learning: in particular those of Ford (1986), Marton and Saljo (1976, 1984), Newble and Entwistle (1986), Entwistle et al. (2004). This work informed development of the project aims and was used to frame survey questions relating to students' approaches to engagement with information for school work.

In a study of learners' ways of thinking about their learning, Ford (1986) interviewed 34 education students and proposed a model which focussed on learners' engagement with differing viewpoints on a topic. His findings suggest that students may engage in deep and/or surface levels of critical thinking and that different IBs are associated with different levels of critical thinking.

The categories Ford identified were:

- Sub-critical thinking: the learner is either unaware of alternative viewpoints (unconscious sub-critical thinking), or is aware of them but does not evaluate them (conscious sub-critical thinking). Ford's data suggested a number of possible reasons, including a lack of intellectual development; the perception that evaluation is not required for an assignment; lack of interest, or that the subject of study may be purely factual.

- Surface-critical thinking: the learner evaluates different viewpoints, but "clinically, without personal involvement" (Ford, 1986, p. 55). Such learners use criteria which they judge to be most acceptable to those marking an assignment. Possible reasons for taking this approach include time pressure, a focus on marks and a lack of interest in the subject.

- Deep critical thinking: the learner evaluates varying viewpoints "to a personally satisfying level" using a number of information sources. Learners engaged in such thinking focus on working out their own viewpoint based on criteria that are satisfying to them. The criteria espoused by students may vary from the criteria used by assessors: in such cases a learner may adhere to his or her own perspectives even if it results in lower marks.

The whole information search process is implicated in Ford's categorisation. Although his focus is on evaluating alternative viewpoints, this is only possible if someone has recognised that they may exist; has selected search sites which may reveal them, and has chosen candidate sources from the material found. Thus an orientation to deep critical thinking will tend to be associated with relatively wide independent information seeking. This is in contrast to the IB of students wishing to find what they perceive to be a factually correct answer (sub-critical) or students focussing on reproducing what they think their teachers want them to say (surface critical). The IB of students in the latter categories is likely to be more dependent on reading lists and/or other specific direction by teachers.

Ford related his research to earlier work into deep and surface approaches to learning. Marton and Saljo $(1976,1984)$ investigated the approaches to learning of Swedish social science students by asking them to read a text. The students were then interviewed about their understanding of the text and their approach to the task. Using what to was become known as the phenomenographic approach, Marton and Saljo (1984) categorised learners as having either a deep approach to learning (seeking to understand the meaning of the text by engaging with it holistically) or a surface approach (atomistic, snatching at parts of the 
meaning and not attempting to see the whole picture). Entwistle (1998) has linked a deep approach to learning with intrinsic motivation of the learner (motivated by feelings of personal satisfaction).

\section{Students' subject preferences}

\subsection{Deep critical thinking and deep critical IB}

Ford (1986) concluded that the types of thinking and their associated IBs which emerged from his study are likely to be influenced by personal (learner) variables. These include learning style, personality, epistemological levels, and strategic choices linked to extrinsic or intrinsic motivational orientations.

Although the description of Ford's deep critical thinking category above, implies deep critical IB, in being open to acquiring, selecting and engaging with information that contributes to different perspectives, the two activities need not be synchronous. We elaborate this relationship in Table I.

Deep critical thinking may take place in the absence of deep critical IB if information is not explicitly sought or encountered in relation to that thinking. This may happen, for example, when a person engages in deep reflection about the logic of different ideas or arguments, isolated from information sources, even though the ideas may have been acquired by past IB.

A person may think critically about an argument they have encountered, but may not critically evaluate the information source that provided the argument. Conversely, a person may critically evaluate the reliability of an information source and question its representation of a particular argument, whilst accepting the argument in an uncritical way.

\subsection{Other studies linking IB with approaches to learning and thinking}

Limberg (1999) worked with 25 Swedish high school students who had been given the task of researching the consequences of a possible Swedish EU membership. After interviewing the students about their information seeking, she identified three qualitatively different categories of information-seeking experience. In category A (labelled "Fact-finding" by Limberg), ease of access was regarded as important and few sources were used. This accords with Ford's (1986) sub-critical approach. By contrast, students with Category C information-seeking experiences ("Scrutinising and analysing") engaged with a variety of sources in order to understand a topic. Limberg (with reference to Marton and Saljo, 1976) related these categories to a surface/deep learning approach to research: "Students made efforts to relate information sources to one another, to interpret information with regard to underlying motives and values and to relate parts to whole in order to discern patterns and construct their understanding of the topic" (Limberg, 1999, p. 126). This focus on their own understanding indicates a deep critical approach to the information task.

\begin{tabular}{|c|c|c|c|c|}
\hline $\begin{array}{l}\text { Deep critical } \\
\text { thinking }\end{array}$ & $\begin{array}{l}\text { The focus is } \\
\text { on the } \\
\text { viewpoint/ } \\
\text { argument }\end{array}$ & $\begin{array}{l}\text { Evaluate the relative } \\
\text { merits of competing } \\
\text { viewpoints/arguments } \\
\text { in relation to a } \\
\text { particular issue }\end{array}$ & Viewpoint/argument (A) & Viewpoint/argument (B) \\
\hline $\begin{array}{l}\text { Deep critical } \\
\text { information } \\
\text { behaviour }\end{array}$ & $\begin{array}{l}\text { The focus is } \\
\text { on the } \\
\text { information } \\
\text { source }\end{array}$ & $\begin{array}{l}\text { Evaluate the relative } \\
\text { merits of different } \\
\text { pieces of information in } \\
\text { terms of contributing to } \\
\text { a varied and nuanced } \\
\text { perspective on the issue }\end{array}$ & $\begin{array}{ll}\text { Information } & \text { Information } \\
\text { (A i) relating } & \text { (A ii) } \\
\text { to A } & \text { relating to A }\end{array}$ & $\begin{array}{ll}\text { Information } & \text { Information } \\
\text { (B i) relating } & \text { (B ii) } \\
\text { to } \mathrm{B} & \text { relating to } \mathrm{B}\end{array}$ \\
\hline
\end{tabular}

Table I. Characteristics of deep critical thinking and deep critical IB 
JD

74,4

696

Students with Limberg's category B experiences ("Balancing information in order to choose right”, Limberg, 1999, p. 126), did not engage critically with the ideas. As a result, they found it difficult to identify materials relevant to both sides of the argument and thus present the "balanced" view they thought necessary. Thus, in Ford's (1986) categorisation, they might be described as actually engaging in sub-critical thinking (not evaluating arguments) but oriented to trying to engage with critical thinking (realising that some evaluation is necessary, whilst failing to achieve this). Their inability to identify the bias and nuances in the material they examined meant that they could not even achieve a surface-critical approach.

Connaway et al. (2011), in a mixed methods, multi-phase investigation into IB and sense-making, found that both student and faculty respondents identified convenience (both in terms of access and time) as a critical factor in shaping their searches. One strand of the IB literature identifies the widespread practice amongst students of this "least effort" approach to information seeking, evaluation and use, with relevance being judged on the basis of convenience, rather than critical evaluation of the information available (Dresang, 2005; Heinström, 2006; O’Brien and Symons, 2005; Urquhart and Rowley, 2007).

There is evidence that such a "least effort" principle covers different stages of the information-seeking process: failing to identify information needs (Walraven et al., 2008); selecting only familiar search tools (with reliance on major search engines: establishing what Olsen and Diekema (2012) describe as an "information comfort zone"); adopting unsophisticated search strategies (Timmers and Glas, 2010); failing to reduce large volumes of information; spending little time assessing the accuracy, authority or relevance of sources before drawing on them for academic work; and accepting poor quality information (e.g. Georgas, 2014; University College London, 2008; Julien and Barker, 2009; Branch, 2003).

In many studies there is implicit or explicit criticism of the sources that learners turn to as convenient and familiar, notably when these sources are Google and Wikipedia. For example, Judd and Kennedy (2011), in their study of medical students' IB at a North American university, noted that first year students used Google and Wikipedia for nearly 80 per cent of their searches. They suggest that:

[...] students' reliance on and familiarity with known tools such as Google and Wikipedia may be contributing to underlying information literacy problems (Judd and Kennedy, 2011, p. 359).

Julien and Barker (2009), however, report an "uneasy tension" (p. 3) amongst high school students using Wikipedia, suggesting that IB associated with its use is more nuanced than some commentators imply, In particular, activities in which students engage in critiquing and editing Wikipedia have been identified as improving learners' critical abilities (e.g. Walker and Li, 2016).

So far the focus has been on learners' characteristics: however, in a formal education context, learners are normally seeking information for a specific academic task, in a given learning and teaching context. Newble and Entwistle (1986) added a third approach to learning, in addition to "surface" and "deep": the strategic approach. This is:

$[\ldots]$ much more influenced by the context than by the nature of the task itself. In any given learning situation there may be some difficulty in distinguishing them from students using deep and surface approaches because they use whatever process they believe is likely to achieve high grades (Newble and Entwistle, 1986, p. 168).

Newble and Entwistle (1986) note that the context for learning (notably, how the teachers teach) will have an impact on the learners' approach to learning. Both Newble and Entwistle's (1986) strategic approach to learning and Ford's (1986) surface-critical approach can be identified as extrinsically motivated strategies (e.g. motivated by external rewards). This brings into the picture the learning task, the teacher setting the task, and the 
educational context in which it is set. Influential on all these elements is the nature of the discipline or subject to which the task relates.

This relationship was elaborated in the research-based model that emerged from the large scale project investigating Teaching-Learning Environments in Undergraduate Courses (Entwistle et al., 2004). This identifies the teacher, and his/her subject knowledge and pedagogical beliefs, and the influence of the (disciplinary) academic community, as well as learners' characteristics, experience and approach to study, as important determinants of the quality of learning (Entwistle et al., 2004). These elements will be elaborated in the following sections.

\subsection{Learners' epistemological understandings}

The epistemological beliefs of students (i.e. beliefs about learning and knowing) also appear to affect their IB. Schommer (1990) proposed five dimensions of personal epistemology: “(a) 'Knowledge is simple rather than complex' (Simple Knowledge), (b) 'Knowledge is handed down by authority rather than derived from reason' (Omniscient Authority), (c) 'Knowledge is certain rather than tentative' (Certain Knowledge), (d) 'The ability to learn is innate rather than acquired' (Innate Ability), and (e) 'Learning is quick or not at all' (Quick Learning)" (Schommer, 1990, p. 499).

Schommer (1990) tested her ideas by administering a questionnaire with items relating to each dimension, and following this up with comprehension experiments. She found that the learners' epistemological beliefs seemed to affect how they interpreted the information they found. Thus for example, when students with "strong beliefs in the certainty of knowledge" (who would map well onto Ford's (1986) sub-critical or surface categories) came across more ambiguous content, their view of knowledge lead "to the distortion of information in order to be consistent with this belief" (Schommer, 1990, p. 503).

Such distortions may have an impact on the way that students search for information. A sample of 290 Iranian undergraduate students who completed an Epistemic Beliefs Inventory (based on Schommer's work), together with a questionnaire on IB based on the model developed by Wilson (2000) showed a positive correlation between the sophistication of their epistemic beliefs and their searching behaviour: i.e. those with more complex epistemic beliefs also had more complex approaches to IB (Mokhtari, 2014).

\subsection{Critiquing the theoretical framework adopted for this study}

The deep/surface distinction used as the theoretical framework for this study has arguably become widely accepted and well-established. It has been the subject of numerous studies across different levels of education (e.g. Booth et al., 1999; Dart et al., 2000) and has been tested for validity and reliability (e.g. Wong et al., 1996).

However, the deep/surface dichotomy - particularly its normative associations whereby deep is deemed preferable to surface - has been criticised as too simplistic, and as emanating and being sustained from a limited Western perspective. Biggs (1994) noted the paradox whereby Chinese students emanating from learning environments emphasising rote learning and memorisation in fact can display high levels of achievement. In this context memorisation may be an integral part of coming to understand at a deep level. Other authors have suggested that it may be a misconception to assume a dichotomous distinction between deep and surface elements of learning, particularly in the case of high achieving Asian students (e.g. Kember, 2000; Hung et al., 2016; Webb, 1997).

Marton and Booth (1997, p. 39), however, drew on a study of teacher educators to identify that the Chinese learner's experience of memorisation may differ from that of a western student:

For them, the process of repetition contributes to understanding because different aspects of the text are in focus with each repetition, which is different from the mechanical memorization which characterises rote learning. 
JD

74,4

698

Webb (1997, p. 207), in his critique of phenomenography, goes further in suggesting that from a hermeneutic perspective, a dichotomous distinction between deep and surface may not map onto the real-world complexity of learning:

Learning, in this view, may be interpreted as the constant movement from part to whole. A simple example for illustration may be seen in the relationship between understanding the words of a sentence and the sentence itself. The idea of the hermeneutical circle describes movement from the word to the sentence, back and forth, in a constant search of understanding and greater illumination. It could just as easily be applied to the movement from surface (signifier) to deep (signified), back and forth, in the quest for understanding. Such movement would, of course, be equally possible for the Western and Chinese learner.

However, it can be noted that a deep learning approach does not preclude paying attention to detail, and may well involve examination of part and whole in a similar iterative way. It is also feasible that deep critical and surface-critical IB could coexist and be intertwined; deployed by an individual in such a hermeneutic circle.

It should also be noted that the well researched and established status, and relatively well developed measures of the deep and surface learning constructs are not shared by the deep critical and surface-critical constructs which form the basis of the current paper. The former relate to understanding information, the latter to seeking and critically evaluating alternative pieces of information. Information deeply understood may not necessarily be subjected to the critical evaluation of its accuracy and value. Compared to deep and surface understanding, deep and surface-critical IB have been the focus of less research effort. In this context, the current paper reports what is essentially an exploratory rather than definitive study, offering tentative - though evidence-based - ideas to be further tested and refined in future research.Future research could usefully investigate further alternative conceptualisations and measurements of deep and surface-critical IB.

\subsection{Disciplinarity in relation to IB and teaching}

Two ways of categorising disciplines have been particularly influential: those of Biglan, in particular as adopted by Becher and Trowler (2001) and those of Whitley (2000). We chose to use the Becher/Biglan approach to categorisation of disciplines for this study's analysis as Whitley's approach is more centrally focussed on the discipline's research community, and less focussed on the discipline's epistemology.

In Biglan's (1973) study, faculty members at the University of Illinois and at a small liberal arts college were asked to make judgements about the similarity of academic areas. Their judgements were subjected to a multivariate analysis from which Biglan identified the now familiar dimensions of hard/soft and pure/applied. According to this classification, a hard pure discipline (e.g. physics) has strong predictability and consensus about the most important research questions, and new knowledge emerges through discovery; whilst a hard applied discipline (e.g. engineering) draws on hard pure knowledge but applies it in a practical context so that the importance of research questions may be driven by real-world needs, and new knowledge may be experienced as outcomes or products deemed useful.

By contrast a soft pure discipline (e.g. history) is likely to develop more recursively, with the field of knowledge consisting of clusters of ideas rather than evident "building blocks", and with a lack of consensus on what constitutes an authentic contribution to knowledge. A soft applied discipline (e.g. education) draws on other knowledge domains to interpret and understand situations, and the outcomes of research may be protocols or procedures which aim to enhance social or personal life in some way (Webber, 2003; Becher and Trowler, 2001).

Neither Becher and Trowler (2001) nor Whitley (2000) saw these as straightforward categorisations. All considered the context of research (e.g. the structure and politics of the higher education system) to be crucial, and the problems of categorising a discipline 
(which may consist of varied and changing sub-disciplines) were recognised. In the volume which succeeds Becher and Trowler (2001), Trowler et al. (2014) debate the nature of disciplines in the 21st century, from a social practice perspective. They note increasing impact from cross-disciplinary factors (e.g. economic pressures and a managerialist Higher Education environment) which may mute disciplinary difference. However, they assert that "seismic shifts are not all in one direction" (Trowler, 2014, p. 38) with movement towards disciplinary silos as well as away from them, towards interdisciplinarity. Trowler et al. (2014) conclude that there are still important differences in the way that teaching and research is carried out in different disciplines.

Hjørland's socio-cultural perspective has relevance here, he claims that:

[...] tools, concepts, meaning, information structures, information needs, and relevance criteria are shaped in discourse communities, for example, in scientific disciplines, which are parts of society's division of labor (Hjørland, 2002, p. 258).

Whilst disciplinary discourse communities open to learners as well as teachers have tended to exist at tertiary education levels, there is increasing interest, particularly in North America, in "Disciplinary Literacy" for students at pre-University level. This movement fosters "reading for understanding", and recognises the multi-modal way in which young people read information, with "a focus on the specific ways a content area thinks, uses language, and shares information" (Mongillo, 2017, p. 331), even in the elementary classroom. Goldman et al. (2016) outline a theoretical framework of learning goals for disciplinary literacy in history, science and literature, and envisage formation of "classroom disciplinary communities" (p. 223). They propose "inquiry practices" and "forms of information representation" as two of the core constructs which vary between disciplines. They contrast, for example, science practice, which builds scientific knowledge through logical explanation and evidence, and historical enquiry, which weighs competing narratives about past events, with the potential for unreliability and misrepresentation.

There is less research into disciplinary differences at the secondary education level than the tertiary, but Madden et al. (2007) report on an English study into the behaviour of children seeking information for school homework. Data collection methods included focus groups, and use of handheld devices to collect information from a pool of 295 learners aged between 11 and 16. Students were asked about information sources they had used for homework. The researchers found significant variation between the number of resources used for the different subjects. The variation was particularly strong amongst key stage 4 (KS4) students (aged 14-16) "where the mean number of resources ranges from 1.75 per homework (for maths) up to 3.00 (for Art)" (Madden et al., 2007, p. 350).

At the university level, Urquhart and Rowley (2007), in a model of IB derived from analysis of the large scale Joint Information Systems Committee User Behaviour Monitoring and Evaluation project, identify "discipline and curriculum" as a factor with direct impact on students' IB. They reported discipline-related differences in the use of e-journals as a specific example.

Whitmire (2002), in a survey of 5,175 North American students found that students studying soft subjects (humanities, business, social sciences, and education) engaged in significantly more information-seeking activity than students studying hard (physical sciences and engineering) subjects; and that students of pure subjects (physical sciences, humanities, and social sciences) engaged in more information-seeking activities than those studying applied subjects (engineering, business, and education). She also found that students studying life subjects (social sciences and education) engaged in more information seeking than those in non-life subjects (physical sciences, engineering, humanities, and business). Disciplines classified as social sciences included "anthropology, economics, political science, psychology, sociology, etc.”. 
JD

74,4

700

Students from soft subjects also display more confidence in their information skills than those from hard subjects. Pinto and Sales (2014) received completed information competencies self-assessment questionnaires from 1,420 undergraduates from 17 departments in a Spanish university. Students from the arts, and the social sciences and law faculties rated their skills higher than did students from the sciences, health sciences and engineering faculties.

Whilst there are also some studies (e.g. Lee, 2008) which link differences in IB more to institutional and personal contexts, there is a substantial body of evidence that links disciplinary differences to differences in IB. Research evidence thus supports the view that disciplinary differences affect the way in which people engage with information.

Urquhart and Rowley (2007, p. 1192) note, however, that "it is important to recognise that these [differences] are often closely linked with the type of learning and teaching strategies found in the discipline." It is an observation supported by Entwistle (2005) who, summarising results from case studies of ways of teaching and learning in four disciplines, notes that there are differences between the way in which subjects are taught, following the "inner logic of the subject and its pedagogy" [no pagination]. Neuman (2001) reviewed research on disciplinary differences in approaches to university teaching. Findings included that hard disciplines "emphasise cognitive goals such as learning facts, principles and concepts" with "strong emphasis on ability to apply methods and principles" whereas "soft areas place greater importance on broad general knowledge, on student character development and on effective thinking skills such as critical thinking" (Neuman, 2001, p. 138).

Evidence for the impact of this approach in a hard disciplinary context emerged, for example, in Svedin et al.'s (2013) study of first year engineering students. They discovered that a surface approach was the highest predictor of academic success, particularly for students of courses with a mathematics component. They suggest that course design (e.g. focus on one examination) could discourage other approaches to study.

Clearly, as these and other researchers have noted (e.g. Biggs, 1999, p. 30), and as was highlighted in section 2.3, a student's approach to learning may be a response to the teacher's approach to teaching, and thus is not fixed. This might be most obvious where students tailor their response to what they believe are their teachers' requirements (a surface approach according to Ford, 1986); but it could also apply to deep critical learners who have to decide whether to retain or abandon their own critically evaluated viewpoint in a particular teaching context. Anderson and Johnston (2016) also note that a teacher with a dualist/realist epistemology may in turn create a learning environment hospitable to an approach that:

[...] would tend to discourage (either actively or by default) the kind of critical thinking that we argue is an essential part of a full information literacy capability (Anderson and Johnston, 2016, p. 59).

Thus, in examining learners' sub-critical, surface-critical or deep critical engagement with alternative viewpoints, we can identify a number of factors that may influence the learners' behaviour. Most research attention has been focussed on learners: what motivates them? what different approaches to learning do they have? how do they perceive knowledge? what is their relationship with particular (familiar) information sources? Where IB is observed to be superficial, blame tends to be assigned (implicitly or explicitly) to the learner for taking a "least effort" approach to the search.

However, we have identified other elements that are also implicated, namely: the task the student has been set, the teacher setting the task, the overall learning and teaching environment, and (affecting all of these elements) the discipline in which the task, teacher and learner are situated. Learner, task, and teacher interact within the discourse and practices of the discipline, bounded by the learning environment. 


\subsection{The educational setting}

In this section we describe key features of the English secondary and tertiary education system relevant to our data collection approach and to interpretation of our findings.

In the methodology outlined below, two hypotheses are postulated:

\section{Students' subject preferences}

H1. Preferences for particular school subjects are associated with differences in IB.

H2. Preferences for particular school subjects have an impact (in the case of university students) on choice of degree.

These are discussed in more detail in the methodology section.

Subjects studied in English schools are dictated by the National Curriculum. This was introduced as part of the UK Parliament's 1988 Education Reform Act. The act identified four key stages (KS) of education between the ages of 5 and 16, and specified attainment targets to be achieved by the end of each Key Stage. The National Curriculum was amended in the Education Act of 2002, and at the time when data were gathered for this research study, all students studying at state schools in England, Wales and Northern Ireland had, during KS 3 (11-14 years), to study the subjects listed in Table II (DfES/QCA, 2004).

After completing key stage 3 (KS3) studies, students in England have some choice in what they study. The most common leaving qualification at age 18 is the advanced level (A level). Most English universities expect students to join a named course and specialise immediately, so school children wishing to go to an English university will select subjects that enable them to choose a degree that suits their interests.

There has been research into what affects students' choices when they move from the core subjects taught at KS3. Jin et al. (2010), in their report on subject and course choice by English school children completing KS3 and KS4, identify that "like doing the subject" was the most frequent factor affecting decisions, outstripping the next most frequent ("Knew I would do well in exam") by nearly 30 per cent. An earlier study into this population (Blenkinsop et al., 2006) found that learners' decision-making processes were complex. The authors' typology of mindsets varied from "Confident aspirational" to "Defeated coper"; but it was noted that learners' decisions were likely to be based on what they currently enjoyed, even when their orientation was towards the future.

However, in Maringe's (2006) study of English students' decisions about university courses, interest in subject was only the fourth strongest factor, behind academic performance in a subject, career possibilities, and teachers' advice.

\section{Methodology}

The methodology adopted for the study consisted of two stages. First, a series of structured interviews was conducted as outlined below (Table III). Questions focussed on students' self-reported IB and on teachers' observations of IB. Since students above KS3 have increasing control over their choice of subjects, connections between academic discipline became more apparent in interviews with older students.

\begin{tabular}{lll}
\hline Core subjects & Foundation subjects \\
\hline English & Art and design & Modern languages \\
Mathematics & Design and technology & Music \\
Science & Geography & Personal, social, health and economic education (PSHE) \\
& History & Physical education (PE) \\
& Information and communication & Religious studies \\
& technology (ICT) & \\
Source: DfES/QCA (2004)
\end{tabular}

Table II.

Subjects compulsory at KS3 
Role of interviewee

Admin and learning support

702

Educator

Student
Librarian

$\begin{array}{lr}\text { Nature of establishment } & \text { No. } \\ \text { School } & 5 \\ \text { FE } & 3 \\ \text { University } & 3 \\ \text { School } & 3 \\ \text { FE } & 3 \\ \text { School } & 5 \\ \text { FE } & 20 \\ \text { University } & 8 \\ \text { School (KS3) } & 33 \\ \text { School (KS4) } & 8 \\ \text { School (sixth Form) } & 2 \\ \text { FE } & 31 \\ \text { University (UG1) } & 14 \\ \text { University (UG2) } & 5 \\ \text { University (UG3) } & 9\end{array}$

In the second stage, a questionnaire was developed in order to test a number of hypotheses. The resultant quantitative data were subjected to statistical procedures comprising clustering and correlation analyses. As well as subject preferences, the questionnaire was designed to investigate students' IB - in particular levels of deep engagement in processing information for their studies.

The hypothesis most relevant to the subject of this paper is that:

[...] preferences for certain school subjects are associated with differences in IB. The research reviewed above suggests that students studying Hard subjects with low task uncertainty are less likely to engage in deep IB than students studying Soft, task uncertain subjects.

However, the data we collected relate to preferences at school. Since many of the responses to the questionnaire were from university students, we thought it prudent to test a second hypothesis, which is that preferences for particular compulsory school subjects (KS3 National Curriculum) have an impact (in the case of university students) on choice of degree. If, for example, a student expressed a preference for soft, pure subjects at school, is that student more likely to study a soft, pure subject at university than a student with different preferences?

\subsection{Data collection}

Interviews. In the first half of 2010, schools, further education (FE) colleges and universities in and around Sheffield were approached with details of the project and with a request for participants. This was to allow study of a cross section of students at all educational levels from KS3 to postgraduate.

Co-operation was received from eight schools, two FE colleges and staff from three universities. All the university students interviewed were from the University of Sheffield. They responded to a posting on the University's volunteer list, or were recruited via departmental contacts.

Data collection was carried out in accordance with the University of Sheffield's policies on research ethics. All interviewees were informed of the purpose of the project, were promised anonymity, and were assured that they could withdraw from the project at any time.

Between November 2010 and July 2011, 152 students, educators, librarians and support staff from participating establishments were interviewed. A summary of interviewees is presented in Table III. 
Questionnaire. The questionnaire (Appendix) was distributed to schools, colleges and universities in the north of England, after being piloted in the University of Sheffield. In addition to the establishments referred to earlier, a further three universities allowed the questionnaire to be distributed. Minor modifications were made according to the nature of the educational establishment.

A total of 1,375 students at educational levels ranging from key stage 3 (KS3) (11-13 years old) to postgraduates (Table IV) were surveyed. All university students were recruited through volunteer lists and completed the survey online. School students and students at $\mathrm{FE}$ colleges were given questionnaires by teachers who had participated in the project. Students who chose to answer the questions handed the completed forms to their teachers.

In order to ensure that respondents had had comparable school experiences, students in post-compulsory education were asked if they were educated in England. Responses from students educated elsewhere were excluded from the analysis.

The questionnaire was designed to explore the role of the following factors in IB:

- intrinsic/extrinsic motivation;

- engagement in deep critical IB;

- subject preference;

- level of educational experience; and

- Wikipedia use.

In addition, it asked students to nominate the three National Curriculum subjects they liked the most and the three they disliked the most (see Table II for the full list of subjects). Students in post-compulsory education were asked to select the subjects they liked and disliked "when you were at school". Physical education and Music were excluded from the options because, up to KS3, the emphasis for these two subjects is more on performance than traditional academic work (DfES/QCA, 2004).

\subsection{Data analysis}

The interview recordings were transcribed and analysed using a thematic approach. This iterative process involved: inductive coding of emergent themes; coding of concepts in the theoretical framework (e.g. quotations that could be interpreted as evidence of a surface approach to learning); coding using frameworks the relevance of which emerged during the analysis process, One such theme which emerged early on was the association between subject of study and IB. Identification of this theme led to use of the Biglan/Becher framework for disciplinarity, and the questionnaire survey being adapted to include questions about subject preference. Several of the interviewees explicitly compared the IB associated with their subject to the IB they saw in other subjects. Quotations indicative of such comparisons are presented in the results section (4.2) below.

A cluster analysis was carried out on the lists of subject preferences declared by students in the survey, and was used to generate the dendrogram in Figure 1. Dendrograms are tree-like diagrams "which indicate the affinity of taxa to their nearest relatives" (Sokal and Rohlf, 1962). In this case the taxa were preferences for subjects on the National Curriculum. The most

\begin{tabular}{|c|c|c|c|c|c|c|c|}
\hline & Key stage 3 & Key stage 4 & A Level/BTech & $\begin{array}{l}\text { Undergraduate } \\
\text { (years 1-3) }\end{array}$ & $\begin{array}{l}\text { Undergraduate } \\
\text { (years } 4+\text { ) }\end{array}$ & Postgraduate & Table IV. \\
\hline Total & 203 & 121 & 255 & 559 & 53 & 165 & $\begin{array}{l}\text { Numbers of } \\
\text { UK-educated students }\end{array}$ \\
\hline M & 104 & 55 & 110 & 199 & 21 & 49 & responding to the \\
\hline $\mathrm{F}$ & 99 & 66 & 145 & 360 & 32 & 116 & questionnaire \\
\hline
\end{tabular}


$\mathrm{JD}$

74,4

704

Figure 1.

Dendrogram using average linkage

(between groups)

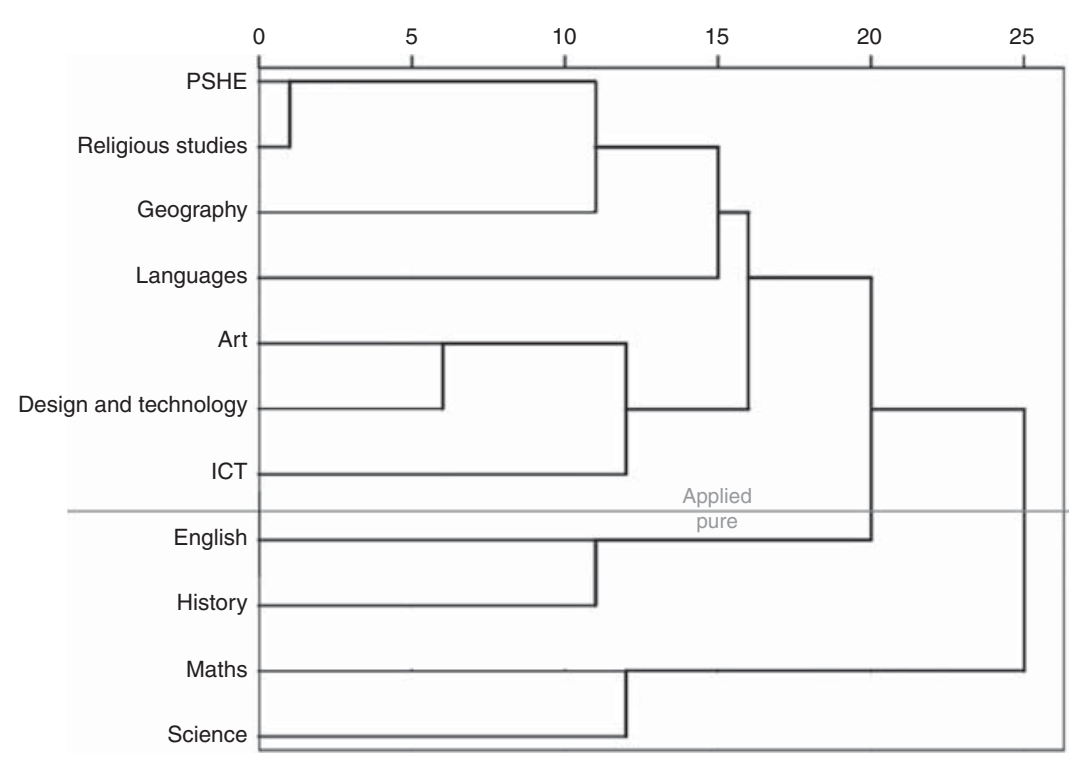

commonly grouped preferences are indicated by the proximity of subjects in the dendrogram (Figure 1); for example, students who prefer maths are also likely to prefer science. The most fundamental separation of preferences (the right-most fork of the dendrogram) suggests that students show a clear preference for either pure or applied subjects.

Whitmire's findings (Whitmire, 2002) clearly indicated differences between the IB of students studying hard and soft subjects at US universities. This analysis was supported in part by Rozaklis (2012), but her findings also suggested that a confounding factor may be whether a subject was pure or applied.

To test the effects of a preference for hardness on IB, a variable was calculated based on students' preferences for maths and ICT (Tables V and VI). Both can reasonably be regarded as hard disciplines. Since one (maths) is pure while the other (ICT) is applied, a liking for both or a dislike of both suggests that their hardness plays a more significant part in the students' stated preferences than whether they are pure or applied.

\begin{tabular}{|c|c|c|c|c|}
\hline & & & ICT & Maths \\
\hline & & & \multicolumn{2}{|c|}{ (\% likes) } \\
\hline 1 & Student likes both maths and ICT & 105 & 33.0 & 20.0 \\
\hline 2 & Student likes one & 440 & 44.0 & 57.3 \\
\hline 3 & Student neither likes nor dislikes either & 145 & \multicolumn{2}{|c|}{ (\% dislikes) } \\
\hline 4 & Student dislikes one & 344 & 34.4 & 51.1 \\
\hline 5 & Student dislikes both & 130 & 34.4 & 31.4 \\
\hline
\end{tabular}

\section{Table VI.}

Number of students who liked just one of the two subjects (maths or ICT)
Student likes maths

but dislikes ICT

Student likes ICT but

dislikes maths 
Two subsets of the questionnaire data were therefore selected. First, to test $H 1$, responses from university students were analysed. Their subjects of study were given a score of 1 (hard) or 2 (soft). This was correlated against their score for like or dislike of maths and ICT (Table VII).

To test $H 2$, responses from the 105 students who expressed a liking for both maths and ICT were compared with those from the 130 students who expressed a dislike for both the subjects (Tables VIII and IX) using Spearman's rank correlation.

Spearman's rank correlation was used in both cases because it is a non-parametric test. It therefore makes few assumptions about the data sets being compared. This makes it less sensitive than other tests of correlation, so if a result is shown to be statistically significant, it can be accepted with greater confidence. Spearman's was also used to test whether preferences for particular school subjects had an impact on choice of degree (Table VII).

\begin{tabular}{lcc}
\hline & Correlation & Significance level \\
\hline $\begin{array}{l}\text { Hard/soft } \\
\text { (hard }=1, \text { soft }=2)\end{array}$ & 0.274 & $p<0.001$ \\
Note: $n=758$ & & \\
\hline
\end{tabular}

Table VII. Spearman correlations between maths/ICT preference index and choice of hard or soft course at university

\begin{tabular}{lcc}
\hline & Correlation & Significance level \\
\hline I like subjects that give me the opportunity to express my own opinions & -0.327 & $p<0.001$ \\
I like subjects where there are clear right and wrong answers & 0.454 & $p<0.001$
\end{tabular}

Notes: $n=235.1=$ Strongly agree, $5=$ Strongly disagree. Negative correlations indicate that students with a dislike of maths/ICT were more likely to agree with the statement than were students who preferred them

Table VIII.

Significant Spearman correlations between the maths/ICT index and questions relating to subject preference

Correlation Significance level

(a) When I am given a piece of work to do I have to find information for $\quad-0.328 \quad p<0.001$ myself in order to do the work

When I am given a piece of work that involves finding information for myself [...]

(b) I feel confident that I will be able to find the information I need $\quad-0.131 \quad p<0.05$

(c) I get satisfaction from knowing my information has come from a $\quad-0.212 \quad p<0.01$ trustworthy source

(d) I put a lot of effort into making sure I get my information from sources $\quad-0.185 \quad p<0.01$ that are trustworthy

When I am doing a piece of work that involves using information I have found for myself

(e) I get better marks when I focus on the most relevant information

(f) I can get good marks without really understanding the information I am using

(g) I get satisfaction from knowing I have understood the information I am using

(h) I put a lot of effort into understanding how all the information fits together before I use it

$-0.208$

$p<0.01$

$p<0.025$

$-0.281 \quad p<0.001$

$-0.151 \quad p<0.025$

Notes: $n=234$. $1=$ Strongly agree, $5=$ Strongly disagree

Table IX. Significant Spearman correlations between the maths/ICT index and questions relating to independent research 
$\mathrm{JD}$

74,4

706

\section{Results}

\subsection{Quantitative analysis}

The quantitative analysis was designed to test the hypotheses that preferences for particular school subjects:

H1. Preferences for particular school subjects are associated with differences in IB.

H2. Preferences for particular school subjects have an impact (in the case of university students) on choice of degree.

The results summarised in Table VII support the $H 2$. If university students correctly recalled their preferences at KS3, then those with a preference for maths and/or ICT were more likely to study hard subjects than soft subjects at university. It is useful to establish this association because the research referred to in the literature review links IB to subject of study, particularly at university. The fact that level of preference for maths/ICT is highly significantly correlated to subject choice supports the relevance of the cited findings to this study.

The hypothesis that a preference for hard or soft subjects affects IB is supported by the results of an analysis in which like or dislike of maths/ICT is correlated with responses to the survey questions, as discussed below, with reference to Tables VIII-X. These analyses used responses from both school and university students.

Subjects associated with relative certainty. As might be expected, students who expressed a liking for maths/ICT were significantly more likely to prefer subjects with clear right and wrong answers, and were less favourably inclined towards subjects which gave them the opportunity to express their own opinions (Table VIII).

Independent research. The significant correlations in Table IX support the findings summarised in the literature survey above, that students studying soft subjects engage in more information-seeking activity than students studying hard subjects. Students who disliked maths/ICT were significantly more likely to report that they were required to find information for their work (Table IX, refer to a). They were also more likely to feel confident of finding the information they needed (Table IX refer to b); to put effort into finding trustworthy sources (Table IX, refer to d), and to derive satisfaction from doing so (Table IX, refer to c).

Students preferring maths/ICT are significantly more likely to hold the view that they can get good marks without really understanding the information they use (Table IX, refer to f). This may explain why they seem less motivated to seek for and to evaluate information than students who dislike maths/ICT (Table IX, refer to e, g, h).

Wikipedia. Frequent, uncritical use of Wikipedia has been seen as indicative of surface IB (Judd and Kennedy, 2011; Rozaklis, 2012). Analysis of the questionnaire results revealed several differences in attitudes to Wikipedia between students who liked and disliked maths/ ICT (Table X). Those who liked the subjects were significantly more likely to regard Wikipedia as a reliable source, to use information from it in their course work, and to feel able to distinguish between accurate and inaccurate information (Table X, refer to a, c, d). They were also significantly less likely to be told not to use it by their teachers (Table X, refer to b).

Table X.

Significant Spearman correlations between the maths/ICT index and questions relating to use of Wikipedia

\begin{tabular}{lll}
\hline & Correlation & Significance level \\
\hline
\end{tabular}

(a) Wikipedia is a reliable source

(b) My teachers tell me NOT to use Wikipedia for my school work

(c) I use information from Wikipedia in my school/university work

(d) I can tell whether the information on Wikipedia is true or not

Notes: $n=231.1=$ Strongly agree, $5=$ Strongly disagree

$\begin{array}{rl}0.292 & p<0.001 \\ -0.159 & p<0.025 \\ 0.323 & p<0.001 \\ 0.134 & p<0.05\end{array}$


This could reflect teachers incorporating Wikipedia into academic practice: the Wikiproject mathematics started in 2002 (Wikipedia, 2017), for example. Tomaszewski and MacDonald (2016), in their study of citations to Wikipedia in academic articles, identified the disciplines with the highest number of citing articles as being computer science and engineering, with mathematics also making "notable use". Similarly Tohidinasab and Jamali (2013) identified computer science as the highest citer of Wikipedia, with Wikipedia being used for facts and definitions as well as general background information.

\section{Students' subject preferences}

\subsection{Relevant insights from qualitative analysis}

The differences between the IB associated with hard and soft subjects were highlighted in an interview with a final year physics undergraduate, who contrasted his IB with that of his girlfriend:

[...] you could do all of my subjects without looking in any book and that's completely in contrast to [name of girlfriend] who does law, who has to look in books. [In physics] The lecturers' notes are more than enough to get a first.

His girlfriend, he observed "[...] is amazed about the lack of work I have to do. Because she has to read the book and she has to learn these facts [...] Whereas I can just learn one technique".

It was an observation corroborated by his girlfriend who noted (in a separate interview) that:

With law there's just so much to read you couldn't read all [...] I think part of what they want you to do actually is to realize what you should be reading and what you shouldn't be reading and what you should be skim reading.

In other words, she was expected to be sufficiently information literate to scope and plan her information gathering, and to evaluate the material with which she engaged. For her to do well, she had to engage critically with her reading material and demonstrate the ability to apply legal principles when interpreting it.

The physicist was probably underplaying the amount of effort required by most students attempting to master the techniques to which he was referring. Once he had learned them, however, he could demonstrate mastery of his subject far more succinctly and unequivocally than his girlfriend could hers.

A similar point was made by a college lecturer who taught maths and IT. He expressed the view that:

[...] at the end of the day, there's that sense of drilling that's expected as a skill [...] It's basically that you do it by hard work - you do it by doing the right things in the most accessible way, and you get your maths qualifications by working.

An a level physics student at the same college recognised this "sense of drilling":

$[\ldots]$ rearranging equations is something $[\ldots]$ you have to go home and sort of see how it $[\ldots]$ slots together, so things like little [...] techniques [...] they may expect you to know [...] you have to just go home and just try and work it out.

ICT, like maths, can be often done without recourse to information resources outside the classroom. In a focus group comprising three BTEC ICT students at college, one of the students noted that: "With IT you mainly just learn about the facts". This was in contrast to his experiences of learning history at school where he was presented with "two sides of a story" without it being possible to say "which one was right and wrong." It was an observation remarked upon by another student in the focus group:

IT [...] it's kind of like science or maths: you're either right or you're wrong. When you get an equation there's no two sides to the story. It's just an answer and there's no other answer. 
JD

74,4

708

A comparison between maths and history was also made by one of the maths teachers interviewed. She remembered her own early experiences as an undergraduate:

[...] when I arrived at university I didn't understand there was such a thing as books about maths. I thought maths was something you entirely did in your head, by yourself and solved all the problems from first principles.

Similarly, she expected her current, pre-university students:

[...] to be able to solve problems independently by themselves, and to approach a different type of problem and to come up with a good idea as to how to solve it. And they can only solve what they've been very specifically taught to solve. That's probably the biggest problem.

Reflecting on her own IB, she recalled:

In terms of information gathering I think I learned most from history. I had a very good history teacher when I was about fourteenish, who taught us very well about different sources of information, and usually when I'm looking at the information I think of his opinions more than anyone else.

\section{Discussion}

The research considered in the literature review above supports the view that IB varies according to subject of study. The evidence presented in this paper provides further support for this view as well as suggesting an explanation (see below).

\subsection{An IB perspective of subject classifications}

The quantitative analysis clearly indicates that students who expressed a preference for both maths and ICT were less likely to show deep critical IB than those who disliked the two subjects.

Whether that link is associative or causative is not clear, so two questions are raised that require further investigation:

$R Q 1$. Are students with a preference for maths/ICT and other hard subjects less inclined to show deep critical IB?

$R Q 2$. Does their choice of subjects present them with fewer opportunities to do so?

The qualitative evidence presented in section 4.2 suggests that the latter is the case; and given the link between subject preference at school and subject choice at university (Table VII), the former clearly remains a possibility.

One of the points made by the students and teachers of maths, ICT and physics interviewed was that their subjects rely on drilling and the acquisition of techniques. Once acquired, these techniques allow students to solve problems independently. Such problem-solving is typical of hard subjects. Biglan (1973) suggested that one of the features that determines whether disciplines are hard or soft is the presence of Kuhnian paradigms. Kuhn may have agreed with this analysis. In describing "The Route to Normal Science” (Kuhn, 1996, Ch2), he argued that:

In the absence of a paradigm or some candidate for paradigm, all of the facts that could possibly pertain to the development of a given science are likely to seem equally relevant (Kuhn, 1996, p. 15).

Where a discipline is in this state, Kuhn refers to it as pre-paradigmatic and suggests that the comparison of conflicting ideas is necessary practice, but becomes less so with the emergence of paradigms. Thus, in hard disciplines, which are more likely to have developed paradigms, it is less likely that students (particularly at school level) will be called on to compare conflicting ideas fundamental to the discipline. Therefore there is less opportunity for them to practice and develop deep critical IB. 
[...] prior to, more binding, and more complete than any set of rules for research that could be subject unequivocally abstracted from them.

Applications associated with them:

[...] accompany the theory into the textbooks from which the future practitioner learns his trade. Kuhn (1996, p. 46).

The idea of intellectual tools is well-established in literature relating to the development of consciousness (eg, Dennett, 1996). Richard Gregory, in considering factors that led to the development of science, discussed various "tools of the Mind" (Gregory, 1981, p. 48), including speech, literacy and calculation. Later, he compares what he terms "Potential Intelligence" and "Kinetic Intelligence":

The distinction here is between solutions (or part-solutions) already available, and solutions that have to be discovered.

Potential intelligence is associated with the former. Someone who is aware of the solution to an existing problem can apply that solution and their intelligence to problems that would have been intractable (or inconceivable) before the solution was arrived at:

So education increases our "internal" Potential Intelligence, through giving knowledge of what problem-solvers or aids are available (Gregory, 1981, p. 311).

One key way in which education achieves this is by providing learners with appropriate "tools of the Mind". At an elementary level, these include speech, literacy and calculation. Once acquired, these tools can be used to gain competence in other tools (such as scientific paradigms).

The concept of intellectual tools provides a possible explanation for the observation that students of different subjects display different IBs. In university subjects traditionally classified as hard, students are seeking to acquire the mathematical and paradigmatic tools needed to learn their "trade", and are considered successful if they can demonstrate an understanding of those tools and can independently solve problems associated with them. So, the final year physics undergraduate felt able to complete his studies "without looking in any book" and the college maths teacher, as an undergraduate "thought maths was something you entirely did in your head, by yourself". In both cases, the main focus of their efforts was the acquisition of some challenging tools of the Mind. University students of soft disciplines by contrast, are more likely to be expected to demonstrate the application of intellectual tools acquired at school in order to evaluate, compare and synthesise arguments. Hence, they will be required to engage critically with information from a range of sources.

Unlike the categories hard and soft, classifications of tool acquisition or tool application are not fixed. A subject may be a tool acquisition subject at one level of study and become a tool application subject at a more A level. Scientific paradigms and mathematics are particularly significant sets of intellectual tools, because of their technical difficulty and their relative cultural neutrality. All academic disciplines though, require the mastery of basic techniques or the grasp of key concepts. Students of a foreign language for example, will begin by acquiring basic tools of grammar and lexis. When they have achieved some degree of proficiency, they will be able to apply those tools to an analysis of culture associated with the language of study.

In English schools and colleges therefore, students studying for a General Certificate of Secondary Education (GCSE) are required to demonstrate comprehension and an ability to 
JD

74,4

710

communicate in the language of study (Department for Education, 2015). A level students must, in addition, "engage critically with intellectually stimulating texts, films and other materials in the original language, developing an appreciation of sophisticated and creative uses of the language and understanding them within their cultural and social context" and "develop knowledge about matters central to the society and culture, past and present, of the country or countries where the language is spoken" (Department for Education, 2015).

Students of hard subjects tend only to carry out such critical evaluations once they have demonstrated an ability to use the intellectual tools associated with their discipline. This may not be until they have studied to a postgraduate level. For example, a maths undergraduate, asked to solve a set of differential equations will be able to do so without needing to refer to any other information source. If that same student goes on to study econometrics, he or she may be required to compare and evaluate the assumptions that underpin different mathematical models describing the same aspects of the economy. Shifts of this kind, from acquiring to applying intellectual tools, would lead to more open and less fact-based questions. Such questions would be more conducive to deep IB.

Some of the possible associations between IB and tool acquisition/application suggested by the research reported here are summarised in Figure 2. Students engaged in tool acquisition can often successfully rely on a limited number of sources (e.g. textbooks, teachers, standard formulae). Such sources (whether textbooks or Wikipedia) divulge well-established facts and explanations which are accepted as authoritative. An example of such IB was discussed by Goldman et al. (2016), who note the importance of the explanatory argument in science, in contrast to the competing narratives explored by history students, who have to consider the possibility that some of the narratives may not be true. Such a consideration is, however, important to students who are determining how best to apply tools acquired through earlier study. As shown in Figure 2, this is likely to affect associated information-related activity.

Whilst both tool acquisition and tool application subjects involve understanding as opposed to mere rote learning, there is a different balance of emphasis between the two. An authoritative source in a tool acquisition subject is one that accurately presents the core ideas: it is not necessarily the original source for those ideas. With paradigmatic disciplines, this has the ironic consequence that reference to original sources is often implicit, and they are used but not cited. So for example, a student of physics is far more likely to look up Newton's laws of motion on Wikipedia than to reference Naturalis Principia Mathematica. However, Wikipedia's description of the laws is probably easier for a twenty-first century student to memorise; and memorisation has a prominent role in gaining mastery of tools of the mind . This, arguably, results in a more narrowly focussed intellectual process than is found with tool application subjects, where the appropriateness of different tools to particular contexts must be considered and evaluated. This links to Pask's (1988) observation that memory plays a more significant role in developing understanding of procedural aspects of a new subject, whilst broader-based integration of new ideas into a learner's existing knowledge is more useful when developing a wider understanding of a subject in context.

A learner's epistemological development, learning approach, motivation, previous experience etc., all influence IB, Figure 2, though, focusses on the disciplinary context and the role of the educator. The challenge for the teacher in scaffolding transition from tool acquisition to tool application mode was well expressed by one of the maths teachers interviewed in the course of this research, namely for students:

[...] to be able to solve problems independently by themselves, and to approach a different type of problem and to come up with a good idea as to how to solve it. And they can only solve what they've been very specifically taught to solve. That's probably the biggest problem. 


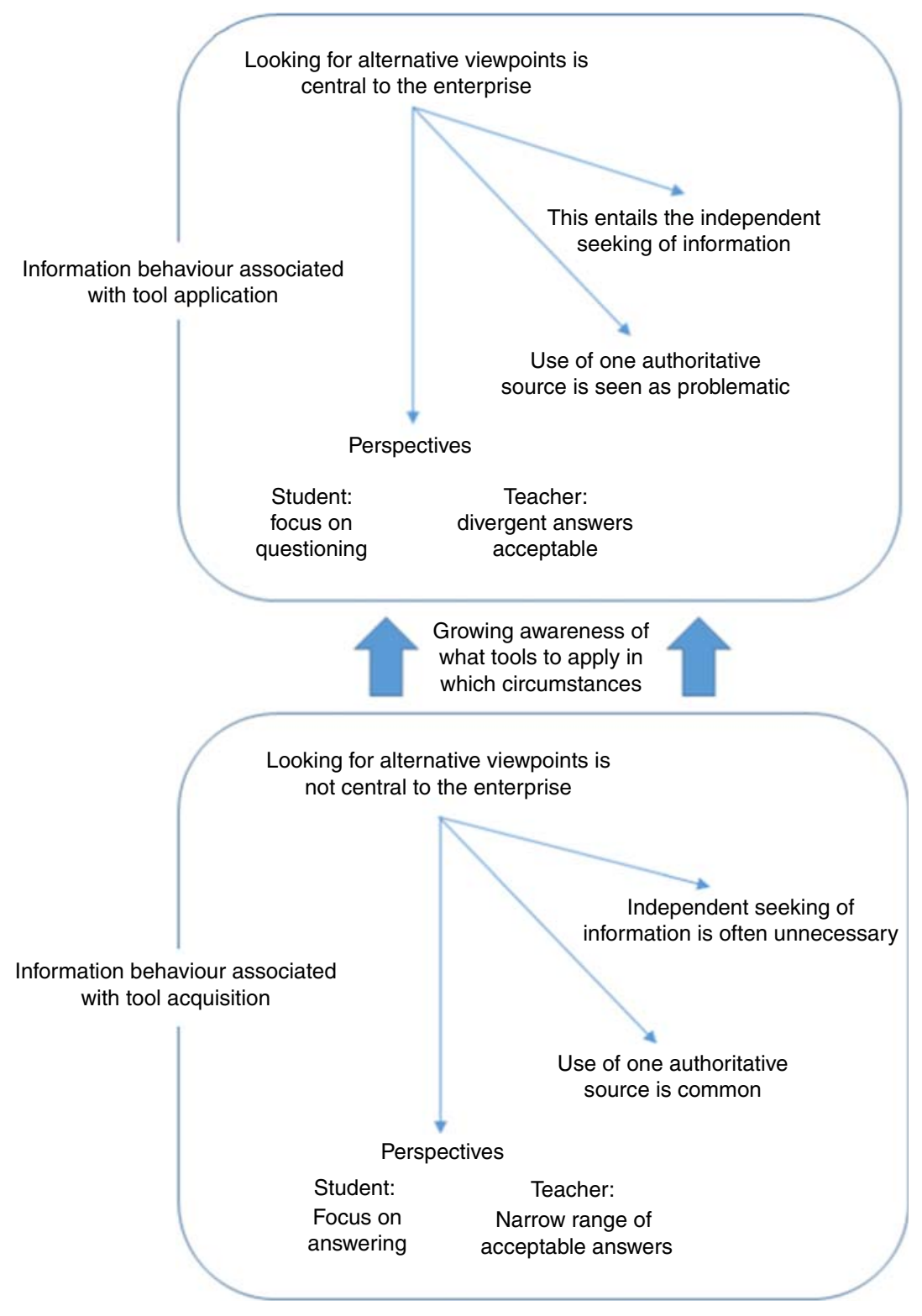

\section{Students' subject preferences}

Figure 2. A model of possible associations between IB and tool acquisition/application

The categories of IB considered in this paper derive directly from Ford's (1986) classification of critical thinking. Table I compares deep critical thinking and deep critical $\mathrm{IB}$, and section 2.2 highlights some of the ways in which the two behaviours may diverge. Such is the case in situations in which the identification and evaluation of competing viewpoints or arguments are not required for the particular intellectual task being performed. Tasks designed to demonstrate the successful acquisition of intellectual tools would be a case in point. 
JD

74,4

In such instances, classification within Ford's (1986) categories of critical thinking are inappropriate. A category of "sub critical IB" would imply an evaluative judgement that the student has failed to engage in appropriate IB. The fact that critical IB is not relevant to the task may be more accurately reflected by the term "a-critical IB", which better represents a legitimate absence of critical IB.

\section{2}

\section{Conclusions}

This paper has made a contribution by providing a new perspective on the relationship between subject discipline and IB, by extending categorisation of IB with a new "'a-critical' category", and by proposing a model of students' engagement with information (Figure 2) using the novel lens of tool application and tool acquisition.

A large body of research suggests a link between academic discipline and IB. This appears particularly marked when comparing students of hard disciplines with students of soft disciplines. Students at schools, FE colleges and universities in and around Sheffield, UK completed a survey of IB. Part of the survey asked them to indicate their preferred subjects in the National Curriculum. Students with a liking for maths and ICT were taken as being representative of learners with a preference for hard over soft subjects. Their responses to the questionnaire suggested that they were significantly less motivated to seek information, and that there was less requirement for them to do so, than was the case with students who expressed a dislike for maths/ICT. Interviews with students and teachers suggested that, in subjects traditionally classified as hard, the main focus was on demonstrating the ability to understand and apply intellectual tools associated with the discipline.

This focus on intellectual tools led to the suggestion that an academic subject can be classified according to whether such tools are being acquired or applied. Such a classification offers more flexibility than Biglan's division of subjects into hard and soft because it recognises that a learners' relationship with a subject may change as the learner progresses. In the early stages of learning a discipline, the focus tends to be on tool acquisition: students are expected to demonstrate a grasp of key terms and concepts. As they learn more, they experience more opportunities to apply intellectual tools that were acquired earlier, both within that discipline and in other areas of their education. The change in relationship, from tool acquisition to tool application, is reflected in changing IB. Opportunities to apply previously acquired intellectual tools come with more broadly focussed assignments of the sort that promote deep, critical IB.

This suggested link between subject of study and IB supports observations by Urquhart and Rowley (2007) and by Entwistle (2005). While it might be the case that some students take a "least effort" approach when finding and evaluating information, it also appears that IB is sometimes influenced by the "inner logic of the subject and its pedagogy" (Entwistle, 2005). The presence of such an "inner logic" suggests the need for an important addition to the classifications of IB derived from Ford (1986) (Table I). This should reflect situations in which the identification and evaluation of competing viewpoints or arguments is not required, or is not relevant to the particular intellectual task being performed. Such is likely to be the case where tools are being acquired, and students are gaining practice in their use.

Extending the "sub critical thinking" category to include such circumstances would be inappropriate because "sub" implies an evaluative judgement that the student has failed to engage in appropriate critical thinking, or that such thinking is inherently less worthy than critical thinking. The fact that critical thinking is simply not relevant to the task may be more accurately reflected by the term "a-critical thinking" which better represents a legitimate absence of critical thinking. 
It should be recalled however, that the quantitative data analysed in this study related to subject preference rather than subject choice. There therefore remains the possibility that lack of desire to engage with information may play a role in determining student preference. Further research in this area would be valuable, and the findings of this article suggest possible directions for such research.

The model outlined in Figure 2 considers possible associations between IB and tool acquisition/application and could provide a framework for investigating teachers' perceptions of their subject by getting them to place it within the model. The well-established hard/soft subject division has allowed some analysis of association between IB and field of study to be carried out in a Higher Education context; but a classification based on whether students are acquiring or applying "tools of the Mind" (Gregory, 1981, p. 48) suggests a potentially valuable approach for analysing the IB of students far earlier in their academic careers. The inclusion of the teacher, the learner and the subject within the model (rather than just focussing on the learner's characteristics) provides a more holistic tool to examine practice within the classroom, and also provides a framework for further research investigation.

\section{Acknowledgements}

This research and its publication was supported by a grant from the Arts and Humanities Research Council. The authors would like to express their gratitude to the many staff at schools and colleges in and around Sheffield who helped to make this research possible, and to the reviewers for their constructive and helpful criticism. Ethical guidelines: the research was carried out in accordance with the University of Sheffield's ethics policy available at www.sheffield.ac.uk/rs/ethicsandintegrity/ethicspolicy/general-principles/ homepage. All interviewees were provided with an information sheet Sheffield. This was presented to volunteers prior to the interview. An edited form of the sheet also formed part of each questionnaire. Conflicts of interest: no conflicts of interest were identified in the course of this research.

\section{References}

Anderson, A. and Johnston, B. (2016), From Information Literacy to Social Epistemology: Insights from Psychology, Chandos Publishing, Kidlington.

Becher, T. and Trowler, P.R. (2001), Academic Tribes and Territories: Intellectual Enquiry and the Cultures of Discipline, 2nd ed., Open University Press, Milton Keynes.

Biggs, J. (1994), "Asian learners through Western eyes: an astigmatic paradox. Australian and New Zealand", Journal of Vocational Educational Research, Vol. 2 No. 2, pp. 40-63.

Biggs, J. (1999), Teaching for Quality Learning at University, SRHE and Open University Press, Buckingham.

Biglan, A. (1973), "The characteristics of subject matter in different academic areas", Journal of Applied Psychology, Vol. 57 No. 3, pp. 195-203.

Blenkinsop, S., McCrone, T., Wade, P. and Morris, M. (2006), How do Young People Make Choices at 14 and 16?, DfES Publications, Annesley.

Booth, P., Luckett, P. and Mladenovic, R. (1999), "The quality of learning in accounting education: the impact of approaches to learning on academic performance", Accounting Education, Vol. 8 No. 4, pp. 277-300.

Branch, J.L. (2003), "Nontraditional undergraduates at home, work, and school: an examination of information-seeking behaviors and the impact of information literacy instruction", Research Strategies, Vol. 19 No. 1, pp. 3-15. 
$\mathrm{JD}$

74,4

714

Case, D.O. and Given, L.M. (2016), Looking for Information: A Survey of Research on Information Seeking, Needs and Behaviour, 4th ed., Emerald Group, Bingley.

Coiro, J., Coscarelli, C., Maykel, C. and Forzani, E. (2015), "Investigating criteria that seventh graders use to evaluate the quality of online information", Journal of Adolescent \& Adult Literacy, Vol. 59 No. 3, pp. 287-297.

Connaway, L.S., Dickey, T. and Radford, M. (2011), “'If it is too inconvenient I'm not going after it:' convenience as a critical factor in information-seeking behaviors", Library \& Information Science Research, Vol. 33 No. 3, pp. 179-190.

Dart, B.C., Burnett, P., Purdie, N., Boulton-Lewis, G., Campbell, J. and Smith, D. (2000), "Students' conceptions of learning, the classroom environment, and approaches to learning", The Journal of Educational Research, Vol. 93 No. 4, pp. 262-270.

Dennett, D.C. (1996), Kinds of Minds: Toward an Understanding of Consciousness, Basic Books, New York, NY.

Department for Education (2015), "Modern foreign languages: GCE AS and A level subject content", available at: www.gov.uk/government/publications/national-curriculum-in-england-languagesprogammes-of-study/national-curriculum-in-england-languages-progammes-of-study (accessed 16 April 2018).

DfES/QCA (2004), The National Curriculum: Handbook for Secondary Teachers in England, Department for Education and Skills/Qualifications and Curriculum Authority, London, available at: http://webarchive.nationalarchives.gov.uk/20130401151715/http://www.education. gov.uk/publications/eOrderingDownload/QCA-04-1374.pdf (accessed 11 May 2017).

Dresang, E.T. (2005), "The information-seeking behavior of youth in the digital environment", Library Trends, Vol. 54 No. 2, pp. 178-196.

Entwistle, N. (1998), "Motivation and approaches to learning: motivating and conceptions of teaching", in Brown, S., Armstrong, S. and Thompson, G. (Eds), Motivating Students, Kogan Page, London, pp. 15-24.

Entwistle, N. (2005), "Ways of thinking and ways of teaching across contrasting subject areas", paper presented at the ISL2005 Conference on Improving Student Learning by Assessment, London, available at: www.etl.tla.ed.ac.uk/docs/etIISL2005.pdf (accessed 11 May 2017).

Entwistle, N., Nisbet, J. and Bromage, A. (2004), "Teaching-learning environments and student learning in electronic engineering", Third Workshop of the European Network on Powerful Learning Environments, Brugge, 30 September-2 October, available at: www.academia.edu/3426418/ Teaching-learning_environments_and_student_learning_in_electronic_engineering (accessed 11 May 2017).

Ford, N. (1986), "Psychological determinants of information needs: a small-scale study of higher education students", Journal of Librarianship, Vol. 18 No. 1, pp. 47-62.

Georgas, H. (2014), "Google vs. the library (Part ii): student search patterns and behaviors when using Google and a federated search tool", Portal: Libraries and the Academy, Vol. 14 No. 4, pp. 503-532.

Goldman, S.R., Britt, M.A., Brown, W., Cribb, G., George, M., Greenleaf, C., Lee, C.D. and Shanahan, C., Project READI (2016), "Disciplinary literacies and learning to read for understanding: a conceptual framework for disciplinary literacy”, Educational Psychologist, Vol. 5 No. 2, pp. 219-246.

Gregory, R.L. (1981), Mind in Science: A History of Explanations in Psychology and Physics, Weidenfeld and Nicholson, London.

Heinström, J. (2006), "Fast surfing for availability or deep diving into quality - motivation and information seeking among middle and high school students", Information Research, Vol. 11 No. 6, available at: http://InformationR.net/ir/11-4/paper265.html (accessed 11 May 2017).

Hjørland, B. (2002), "Epistemology and the socio-cognitive perspective in information science", Journal of the American Society for Information Science and Technology, Vol. 53 No. 4, pp. 257-270. 
Hung, M., Cheng, M. and Wan, Z.-H. (2016), "Unpacking the paradox of Chinese science learners: insights from research into Asian Chinese school students' attitudes towards learning science, science learning strategies, and scientific epistemological views", Studies in Science Education, Vol. 52 No. 1, pp. 29-62.

Jin, W., Muriel, A. and Sibieta, L. (2010), Subject and Course Choices at Ages 14 and 16 Amongst Young People in England: Insights from Behavioural Economics. Research Report DFE-RR160, Department for Education, London.

Judd, T. and Kennedy, G. (2011), "Expediency-based practice? Medical students' reliance on Google and Wikipedia for biomedical inquiries", British Journal of Educational Technology, Vol. 42 No. 2, pp. 351-360.

Julien, H. and Barker, S. (2009), "How high-school students find and evaluate scientific information: a basis for information literacy skills development”, Library \& Information Science Research, Vol. 31 No. 1, pp. 12-17.

Kember, D. (2000), "Misconceptions about the learning approaches, motivation and study practices of Asian students", Higher Education, Vol. 40 No. 1, pp. 99-121.

Kuhn, T.S. (1996), The Structure of Scientific Revolutions, 3rd ed., University of Chicago Press, Chicago, IL.

Lee, H.-L. (2008), "Information structures and undergraduate students", The Journal of Academic Librarianship, Vol. 34 No. 3, pp. 211-219.

Limberg, L. (1999), "Three conceptions of information seeking and use”, in Wilson, T.D. and Allen, D.K. (Eds), Exploring the Contexts of Information Behaviour, Taylor Graham, London, pp. 116-135.

Madden, A., Ford, N. and Miller, D. (2007), "Information resources used by children at an English secondary school: perceived and actual levels of usefulness", Journal of Documentation, Vol. 63 No. 3, pp. 340-358.

Madden, A.D. (2004), "Evolution and information", Journal of Documentation, Vol. 60 No. 1, pp. 9-23.

Maringe, F. (2006), "University and course choice”, International Journal of Educational Management, Vol. 20 No. 6, pp. 466-479.

Marton, F. and Booth, S. (1997), The Experience of Learning, Lawrence Erlbaum Associates, Mahwah, NJ.

Marton, F. and Saljo, R. (1976), "On qualitative differences in learning: I outcome and process", British Journal of Educational Psychology, Vol. 46 No. 1, pp. 4-11.

Marton, F. and Saljo, R. (1984), "Approaches to learning”, in Marton, F., Hounsell, D. and Entwistle, N. (Eds), The Experience of Learning, Scottish Academic Press, Edinburgh, pp. 36-55.

Mokhtari, H. (2014), "A quantitative survey on the influence of students' epistemic beliefs on their general information seeking behaviour", Journal of Academic Librarianship, Vol. 40 Nos 3/4, pp. 259-263.

Mongillo, M.B. (2017), "Creating mathematicians and scientists: disciplinary literacy in the early childhood classroom”, Early Child Development and Care, Vol. 187 Nos 3/4, pp. 331-341.

Neuman, R. (2001), "Disciplinary differences and university teaching”, Studies in Higher Education, Vol. 26 No. 2, pp. 135-146.

Newble, D.I. and Entwistle, N.J. (1986), "Learning styles and approaches: implications for medical education", Medical Education, Vol. 20 No. 3, pp. 162-175.

O'Brien, H. and Symons, S. (2005), "The information behaviors and preferences of undergraduate students”, Research Strategies, Vol. 20 No. 4, pp. 409-423.

Olsen, M.W. and Diekema, A.R. (2012), “I just Wikipedia it': information behavior of first-year writing students", Proceedings of the American Society for Information Science and Technology, Vol. 49, pp. 1-11.

Pask, G. (1988), "Learning strategies, teaching strategies, and conceptual or learning style", in Schmeck, R.R. (Ed.), Learning Strategies and Learning Styles, Springer, Berlin, pp. 83-100. 
JD

74,4

716

Pettigrew, K.E., Fidel, R. and Bruce, H. (2001), "Conceptual frameworks in information behavior", in Williams, M.E. (Ed.), Annual Review of Information Science \& Technology, Vol. 35, Information Today, Medford, pp. 43-78.

Pinto, M. and Sales, D. (2014), "Uncovering information literacy's disciplinary differences through students' attitudes: an empirical study", Journal of Librarianship and Information Science, Vol. 47 No. 3, pp. 204-215.

Powers, E. (2017), "My news feed is filtered? Awareness of news personalization among college students", Digital Journalism, Vol. 5 No. 10, pp. 1315-1335, available at: http://dx.doi.org/10.10 80/21670811.2017.1286943 (accessed 11 May 2017).

Rozaklis, L. (2012), "The academic library in the life of the undergraduate: an investigation of undergraduates' academic information behaviors in the digital age", unpublished $\mathrm{PhD}$ dissertation, Drexel University, Philadelphia, PA.

Schommer, M. (1990), "Effects of beliefs about the nature of knowledge on comprehension", Journal of Educational Psychology, Vol. 82 No. 3, pp. 498-504.

Sokal, R.R. and Rohlf, F.J. (1962), "The comparison of dendrograms by objective methods", Taxon, Vol. 11 No. 2, pp. 33-40.

Sundin, O., Haider, J., Andersson, C., Carlsson, H. and Kjellberg, S. (2017), "The searchification of everyday life and the mundane-ification of search", Journal of Documentation, Vol. 73 No. 2, pp. 224-243.

Svedin, M., Balter, O., Sheja, M. and Pettersson, K. (2013), "A surface approach to learning rewards first-year engineering students", Learning and Teaching in Computing and Engineering IEEE, Macau, 21-24 March, pp. 143-147.

Timmers, C. and Glas, C. (2010), "Developing scales for information-seeking behaviour", Journal of Documentation, Vol. 60 No. 1, pp. 46-69.

Tohidinasab, F. and Jamali, H.R. (2013), "Why and where Wikipedia is cited in journal articles?", Journal of Scientometric Research, Vol. 2 No. 3, pp. 231-238.

Tomaszewski, R. and MacDonald, K.I. (2016), "A study of citations to wikipedia in scholarly publications”, Science \& Technology Libraries, Vol. 35 No. 3, pp. 246-261.

Trowler, P. (2014), "Disciplines and academic practice", in Trowler, P., Saunders, M. and Bamber, V. (Eds), Tribes and Territories in the 21st Century: Rethinking the Significance of Discipline in Higher Education, Routledge, Abingdon, pp. 30-38.

Trowler, P., Saunders, M. and Bamber, V. (Eds) (2014), Tribes and Territories in the 21st Century: Rethinking the Significance of Discipline in Higher Education, Routledge, Abingdon.

University College London (2008), Information Behaviour of the Researcher of the Future, University College London, London.

Urquhart, C. and Rowley, J. (2007), "Understanding student information behavior in relation to electronic information services: lessons from longitudinal monitoring and evaluation, Part 2", Journal of the American Society for Information Science and Technology, Vol. 58 No. 8, pp. 1188-1197.

Walker, M.A. and Li, Y. (2016), "Improving information literacy skills through learning to use and edit Wikipedia: a Chemistry perspective", Journal of Chemical Education, Vol. 93 No. 3, pp. 509-515.

Walraven, A., Brand-gruwel, S. and Boshuizen, H. (2008), "Information-problem solving: a review of problems students encounter and instructional solutions", Computers in Human Behavior, Vol. 24 No. 3, pp. 623-648.

Webb, G. (1997), "Deconstructing deep and surface: towards a critique of phenomenography", Higher Education, Vol. 33 No. 2, pp. 195-212.

Webber, S. (2003), "Information science in 2003: a critique”, Journal of Information Science, Vol. 29 No. 4, pp. 311-330. 
Whitley, R. (2000), The Intellectual and Social Organization of the Sciences, 2nd ed., Oxford University Press, Oxford.

Whitmire, E. (2002), "Disciplinary differences and undergraduates' information-seeking behaviour", Journal of the American Society for Information Science and Technology, Vol. 53 No. 8, pp. 631-638, doi: 10.1002/asi.10123.

Wikipedia (2017), "Wikiproject mathematics”, available at: https://en.wikipedia.org/wiki/Wikipedia: WikiProject_Mathematics (accessed 11 May 2017).

Wilson, T.D. (1981), "On user studies and information needs”, Journal of Documentation, Vol. 37 No. 1, pp. 3-15.

Wilson, T.D. (2000), "Human information behavior", Informing Science, Vol. 3 No. 2, pp. 49-55.

Wong, N., Lin, W. and Watkins, D. (1996), "Cross-cultural validation of models of approaches to learning: an application of confirmatory factor analysis", Educational Psychology, Vol. 16 No. 3, pp. 317-327.

\section{Further reading}

Entwistle, N. (2001), "Promoting deep learning through teaching and assessment: conceptual frameworks and educational contexts", Teaching and Learning Research Programme Conference, Leicester, November, available at: www.tla.ed.ac.uk/et1/docs/entwistle2000.pdf (accessed 11 May 2017).

Marton, F., Dall'Alba, G. and Lai, K.T. (1993), “The paradox of the Chinese Learner”, Educational Research and Development Unit (RMIT) Occasional Paper, Vol. 93 No. 1, pp. 1-17. 
JD

74,4

\section{Appendix}

\section{SECTION 1: ABOUT YOU}

Q.1 What year are you in at school? (Tick one box)

$\begin{array}{ccccc}\text { Year } 7 & \text { Year } 8 & \text { Year 9 } & \text { Year 10 } & \text { Year 11 } \\ \square & \square & \square & \square\end{array}$

Q.2 Are you male or female? (Tick one box)

Male Female

$\square$

Q.3 Please look at the following list of subjects and tell us which THREE you like most and which THREE you like least (tick three boxes in each column):

\begin{tabular}{|l|c|c|}
\hline \multirow{2}{*}{ Art } & Like most & \\
\hline Design and Technology & & \\
\hline English & $\square$ & \\
\hline Geography & $\square$ & $\square$ \\
\hline History & $\square$ & $\square$ \\
\hline ICT & $\square$ & $\square$ \\
\hline Languages & $\square$ & $\square$ \\
\hline Maths & $\square$ & $\square$ \\
\hline PSHE & $\square$ & $\square$ \\
\hline Religious studies & $\square$ & $\square$ \\
\hline Science & $\square$ & $\square$ \\
\hline
\end{tabular}

Q.4 Please tell us how much you agree or disagree with each of the following statements (tick one box on each line):

\begin{tabular}{|c|c|c|c|c|c|}
\hline & $\begin{array}{c}1 \\
\text { Strongly } \\
\text { Agree }\end{array}$ & $\begin{array}{c}2 \\
\text { Agree }\end{array}$ & $\begin{array}{c}3 \\
\text { Neither } \\
\text { agree nor } \\
\text { disagree }\end{array}$ & $\begin{array}{c}4 \\
\text { Disagree }\end{array}$ & $\begin{array}{c}5 \\
\text { Strongly } \\
\text { disagree }\end{array}$ \\
\hline \multicolumn{6}{|l|}{$\begin{array}{l}\text { I like subjects that give me the } \\
\text { opportunity to express my own opinions }\end{array}$} \\
\hline \multicolumn{6}{|l|}{$\begin{array}{l}\text { I like subjects where there are clear right } \\
\text { and wrong answers }\end{array}$} \\
\hline \multicolumn{6}{|l|}{$\begin{array}{l}\text { I feel overwhelmed by the amount of } \\
\text { information I have to deal with at school }\end{array}$} \\
\hline \multicolumn{6}{|l|}{$\begin{array}{l}\text { I find it easy to keep up with all the work I } \\
\text { have to do for school }\end{array}$} \\
\hline \multicolumn{6}{|l|}{$\begin{array}{l}\text { I get better marks when I put a lot of } \\
\text { effort into my school work }\end{array}$} \\
\hline I get poor marks even when I try hard & & & & & \\
\hline
\end{tabular}


Q.5 Please tell us how often the following statements about your school work are true for you (tick one box on each line):

\begin{tabular}{|l|c|c|c|c|c|}
$\begin{array}{l}\text { When I am given a piece of } \\
\text { work to do .... }\end{array}$ & $\begin{array}{c}1 \\
\text { All of the } \\
\text { time }\end{array}$ & $\begin{array}{c}2 \\
\text { Most of } \\
\text { the time }\end{array}$ & $\begin{array}{c}3 \\
\text { Some of } \\
\text { the time }\end{array}$ & $\begin{array}{c}4 \\
\text { Hardly } \\
\text { ever }\end{array}$ & $\begin{array}{c}\text { Never } \\
\text { f. I have to find information for myself in } \\
\text { order to do the work }\end{array}$ \\
\hline $\begin{array}{l}\text {.. I struggle to understand what is } \\
\text { required to do a good piece of work }\end{array}$ & $\square$ & $\square$ & $\square$ & $\square$ & $\square$ \\
\hline
\end{tabular}

Q.6 Please tell us how often the following statements about your school work are true for you (tick one box on each line):

\begin{tabular}{|l|c|c|c|c|c|}
$\begin{array}{l}\text { When I have to find } \\
\text { information for a piece of } \\
\text { Work I am doing .... }\end{array}$ & $\begin{array}{c}1 \\
\text { All of the } \\
\text { time }\end{array}$ & $\begin{array}{c}2 \\
\text { Most of } \\
\text { the time }\end{array}$ & $\begin{array}{c}3 \\
\text { Some of } \\
\text { the time }\end{array}$ & $\begin{array}{c}4 \\
\text { Hardly } \\
\text { ever }\end{array}$ & $\begin{array}{c}5 \\
\text { I understand how I am meant to find } \\
\text { the information I need }\end{array}$ \\
$\begin{array}{l}\ldots \text { I I understand what I need to do with } \\
\text { information once I have found it }\end{array}$ & $\square$ & $\square$ & $\square$ & $\square$ & $\square$ \\
\hline
\end{tabular}

Q.7 When you are doing a piece of work for school, to what extent are you trying to achieve each of the following (tick one box on each line):

\begin{tabular}{|l|c|c|c|c|c|c|}
\hline & $\begin{array}{c}1 \\
\text { the of }\end{array}$ & $\begin{array}{c}\text { Most of } \\
\text { the time }\end{array}$ & $\begin{array}{c}3 \\
\text { Some of } \\
\text { the time }\end{array}$ & $\begin{array}{c}4 \\
\text { Hardly } \\
\text { ever }\end{array}$ & \begin{tabular}{c} 
Never \\
\hline Getting the best mark I can
\end{tabular} \\
\hline Doing the minimum I can get away with & $\square$ & $\square$ & $\square$ & $\square$ & $\square$ \\
\hline Learning as much as I can & $\square$ & $\square$ & $\square$ & $\square$ & $\square$ \\
\hline Pleasing other people (e.g. teachers or parents) & $\square$ & $\square$ & $\square$ & $\square$ & $\square$ \\
\hline Doing enough to avoid failing & $\square$ & $\square$ & $\square$ & $\square$ & $\square$ \\
\hline Being satisfied that I have done my best & $\square$ & $\square$ & $\square$ & $\square$ & $\square$ \\
\hline Getting good qualifications & $\square$ & $\square$ & $\square$ & $\square$ \\
\hline Other (please give details) & $\square$ & $\square$ & $\square$ & $\square$ & $\square$ \\
\hline
\end{tabular}

\section{SECTION 2: FINDING AND USING INFORMATION}

Q.8 Please tell us about your experience of FINDING information to use in your school work by saying how strongly you agree or disagree with each of the following statements (tick one box on each line):

\begin{tabular}{|c|c|c|c|c|c|}
\hline $\begin{array}{l}\text { When I am given a piece of } \\
\text { work that involves finding } \\
\text { information for myself ... }\end{array}$ & $\begin{array}{c}1 \\
\text { Strongly } \\
\text { Agree }\end{array}$ & $\begin{array}{c}2 \\
\text { Agree }\end{array}$ & $\begin{array}{l}\text { 3 } \\
\text { Neither } \\
\text { agree nor } \\
\text { disagree }\end{array}$ & $\begin{array}{c}4 \\
\text { Disagree }\end{array}$ & $\begin{array}{c}5 \\
\text { Strongly } \\
\text { disagree }\end{array}$ \\
\hline $\begin{array}{l}\ldots \text { I feel confident that I will be able to find the } \\
\text { information I need }\end{array}$ & & & & {[} & \\
\hline $\begin{array}{l}\text {... finding the right information takes a lot of } \\
\text { effort }\end{array}$ & & $\square$ & Г & $\square$ & म \\
\hline $\begin{array}{l}\text {... I get better marks when I have to find } \\
\text { information for myself }\end{array}$ & & & 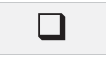 & $\square$ & $\square$ \\
\hline $\begin{array}{l}\ldots \text { I find it more interesting when I have to find } \\
\text { information for myself }\end{array}$ & $\square$ & $\square$ & $\square$ & $\square$ & $\square$ \\
\hline $\begin{array}{l}\text {... I put a lot of effort into finding the information } \\
\text { I need }\end{array}$ & Г & Г & $\square$ & $\square$ & $\square$ \\
\hline $\begin{array}{l}\ldots \text { teachers should give more guidance about } \\
\text { how to find the information I will need }\end{array}$ & $\Gamma$ & 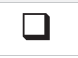 & $\square$ & $\square$ & $\square$ \\
\hline
\end{tabular}


$\mathrm{JD}$

74,4
Q.9 Please tell us about your experience of EVALUATING the information you find by saying how strongly you agree or disagree with each of the following statements (tick one box on each line):

\begin{tabular}{|l|c|c|c|c|c|}
\hline $\begin{array}{l}\text { When I am given a piece of } \\
\text { work that involves finding } \\
\text { information for myself ... }\end{array}$ & $\begin{array}{c}1 \\
\text { Strongly } \\
\text { Agree }\end{array}$ & $\begin{array}{c}2 \\
\text { Agree }\end{array}$ & $\begin{array}{c}\text { Neither } \\
\text { agree nor } \\
\text { disagree }\end{array}$ & Disagree & $\begin{array}{c}\text { Strongly } \\
\text { disagree }\end{array}$ \\
\hline
\end{tabular}

... I feel confident that I can tell whether my information has come from a trustworthy source

... it takes a lot of effort to check whether an information source is trustworthy

... I get better marks when I make sure my information comes from a trustworthy sources

... I get satisfaction from knowing my information has come from a trustworthy source

... I put a lot of effort into making sure I get my information from sources that are trustworthy

... teachers should give more guidance on which sources I should be using

\section{SECTION 3: WORKING WITH INFORMATION}

Q.10 Please tell us about your experience of SELECTING the information you will use in your school work by saying how strongly you agree or disagree with each of the following statements (tick one box on each line):

\begin{tabular}{|c|c|c|c|c|c|}
\hline $\begin{array}{l}\text { When I am doing a piece of } \\
\text { work that involves using } \\
\text { information I have found for } \\
\text { myself... }\end{array}$ & $\begin{array}{l}1 \\
\text { Strongly } \\
\text { Agree }\end{array}$ & $\begin{array}{c}2 \\
\text { Agree }\end{array}$ & $\begin{array}{c}3 \\
\text { Neither } \\
\text { agree nor } \\
\text { disagree }\end{array}$ & $\begin{array}{c}4 \\
\text { Disagree }\end{array}$ & $\begin{array}{l}5 \\
\text { Strongly } \\
\text { disagree }\end{array}$ \\
\hline $\begin{array}{l}\text {.. I feel confident that I will be able to select the } \\
\text { most relevant information from all the } \\
\text { information I have found }\end{array}$ & & & & & \\
\hline $\begin{array}{l}\text {... deciding what information to include and } \\
\text { what to leave out takes a lot of effort }\end{array}$ & & & & & \\
\hline $\begin{array}{l}\text { … I get better marks when I focus on the most } \\
\text { relevant information }\end{array}$ & & & & & \\
\hline $\begin{array}{l}\text {... I find it more interesting when I can see why } \\
\text { things are relevant }\end{array}$ & & & & & \\
\hline $\begin{array}{l}\text {.. I put a lot of effort into working out what } \\
\text { information is most relevant }\end{array}$ & & & & & \\
\hline $\begin{array}{l}\text {... teachers should give more guidance about } \\
\text { what to include and what to leave out }\end{array}$ & & & & & \\
\hline
\end{tabular}


Q.11 Please tell us about your experience of USING information in your school work by saying how strongly you agree or disagree with each of the following statements (tick one box on each line):

\begin{tabular}{|c|c|c|c|c|c|}
\hline $\begin{array}{l}\text { When I am doing a piece of } \\
\text { work that involves using } \\
\text { information I have found for } \\
\text { myself ... }\end{array}$ & $\begin{array}{c}1 \\
\text { Strongly } \\
\text { Agree }\end{array}$ & $\begin{array}{c}2 \\
\text { Agree }\end{array}$ & $\begin{array}{c}3 \\
\text { Neither } \\
\text { agree nor } \\
\text { disagree }\end{array}$ & $\begin{array}{c}4 \\
\text { Disagree }\end{array}$ & $\begin{array}{c}5 \\
\text { Strongly } \\
\text { disagree }\end{array}$ \\
\hline $\begin{array}{l}\text {... I feel confident that I will be able to use the } \\
\text { information in a way that shows I have } \\
\text { understood it }\end{array}$ & & & & & \\
\hline $\begin{array}{l}\ldots \text { it takes a lot of effort to put the information } \\
\text { together in my own words }\end{array}$ & & & & & \\
\hline $\begin{array}{l}\ldots \text { I can get good marks without really } \\
\text { understanding the information I am using }\end{array}$ & & & & & \\
\hline $\begin{array}{l}\ldots \text { I get satisfaction from knowing I have } \\
\text { understood the information I am using }\end{array}$ & & & & & \\
\hline $\begin{array}{l}\text {.. I put a lot of effort into understanding how all } \\
\text { the information fits together before I use it }\end{array}$ & & & & & \\
\hline $\begin{array}{l}\text {... teachers should give more guidance on how } \\
\text { to use the information I find }\end{array}$ & & & & & \\
\hline
\end{tabular}

\section{Students' subject preferences}

\section{SECTION 4: WIKIPEDIA}

Q. 12 Please tell us how much you agree or disagree with each of the following statements about Wikipedia (tick one box on each line):

\begin{tabular}{|c|c|c|c|c|c|}
\hline & $\begin{array}{l}1 \text { Strongly } \\
\text { Agree }\end{array}$ & $\begin{array}{c}2 \\
\text { Agree }\end{array}$ & $\begin{array}{c}3 \text { Neither } \\
\text { agree nor } \\
\text { disagree }\end{array}$ & $\begin{array}{c}4 \\
\text { Disagree }\end{array}$ & $\begin{array}{c}5 \\
\text { Strongly } \\
\text { disagree }\end{array}$ \\
\hline \multicolumn{6}{|l|}{ Wikipedia is a reliable source } \\
\hline \multicolumn{6}{|l|}{$\begin{array}{l}\text { My teachers tell me not to use Wikipedia for my } \\
\text { school work }\end{array}$} \\
\hline Wikipedia is a good place to get basic information & & & & & \\
\hline
\end{tabular}

Q.13 Please tell us about the way you use Wikipedia (tick one box on each line):

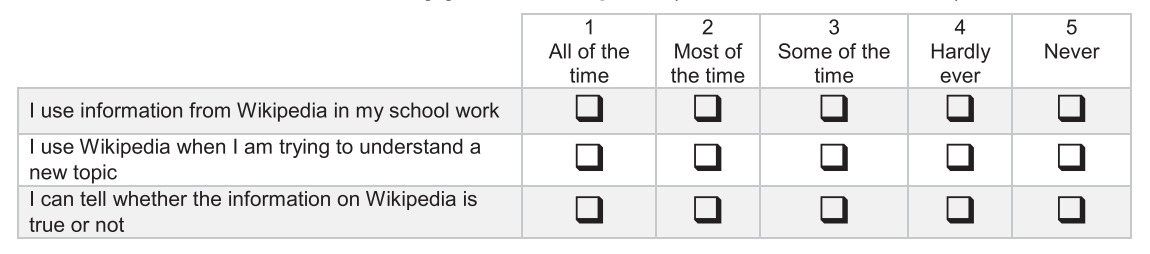

Thank you for completing this questionnaire

Corresponding author

Sheila Webber can be contacted at: s.webber@sheffield.ac.uk

For instructions on how to order reprints of this article, please visit our website:

www.emeraldgrouppublishing.com/licensing/reprints.htm

Or contact us for further details: permissions@emeraldinsight.com 